\title{
Backcross Aiming at the Resistance of Passion Fruit to Soil Pathogen
}

\author{
Antonio Marcos Chimello ${ }^{1,2}$, Geovani Casusa da Silva ${ }^{1}$, Romulo Proença Belisário ${ }^{1}$, Thalita Neves Marostega ${ }^{1,2}$, \\ Sandra da Costa Preisigke ${ }^{1}$, Kelly Lana Araújo ${ }^{1} \&$ Leonarda Grillo Neves ${ }^{1,2}$ \\ ${ }^{1}$ Departamento de Agronomia, Universidade do Estado de Mato Grosso, Cáceres, MT, Brazil \\ ${ }^{2}$ Programa de Pós Graduação em Bitecnologia e Bidiversidade, Rede Pró Centro-Oeste, Universidade do Estado \\ de Mato Grosso, Cáceres, MT, Brazil \\ Correspondence: Antonio Marcos Chimello, Departamento de Agronomia, Universidade do Estado de Mato \\ Grosso, Cáceres, MT, Brazil. E-mail: antoniokimelo@hotmail.com
}

Received: February 3, 2021

Accepted: March 7, $2021 \quad$ Online Published: April 15, 2021

doi:10.5539/jas.v13n5p62

URL: https://doi.org/10.5539/jas.v13n5p62

\begin{abstract}
Brazil is the world's largest producer of passion fruit, however, the crop suffers from serious phytosanitary problems, as well as those caused by soil fungi. Thus, the objective of the present work was to estimate the genetic parameters and to select genotypes resistant to Fusarium solani species complex-FSSC in a segregating population from the first generation of backcross among $P$. edulis and interspecific hybrids, aiming at advancing generation in the genetic improvement program of passion fruit. The Interspecific Hybrid was used (IH) UNEMAT 142 resistant to colon rot, for generation advancement and to cultivate BRS Sol do Cerrado (Passiflora edulis Sims). In order to evaluate the resistance of the 27 genotypes of the first generation of backcrosses, inoculation with the FSUNEMAT 40 ( $F$. solani) inoculum was performed. To estimate the components of variances, the method of maximum restricted likelihood (REML) was used and to select the best genotypes by the non-addicted linear prediction (BLUP). The variables that showed the highest heritability values were the survival period and the area under the lesion length expansion curve. The three families of backcrosses presented genotypes resistant to the fungus $F$. solani, however, by the methodology of mixed models REML/BLUP, only the genotypes BC1-22/1, BC1-22/2, BC1-22/3, BC1-22/4, BC1-22/6, BC1-22/7, BC1-113/3, $\mathrm{BC} 1-113 / 7$ and $\mathrm{BC} 1-113 / 8$, were selected to advance the generation of the UNEMAT passion fruit breeding program, therefore, they presented among the ten placed, mainly for the variable survival period (SP).
\end{abstract}

Keywords: Passiflora spp., plant breeding, Fusarium solani species complex—FSSC, REML/BLUP

\section{Introduction}

The genus Passiflora L. is originally from South America with concentration and distribution in Brazil, Paraguay and northern Argentina, although in some reports it is listed as native to Venezuela and Colombia (Cervi, 1997; Meletti \& Maia, 1999; Dhawan et al., 2004). Brazil is the world's largest producer of passion fruit, with a production of $593.429 \mathrm{t}$ (IBGE, 2020), with passion fruit (Passiflora edulis Sims) accounting for more than 90\% of this production. However, production and productivity have been hindered by several phytosanitary problems, reducing the time of economic exploitation or even preventing their cultivation in some regions.

Among the diseases, the colon rot, caused by Fusarium solani species complex - FSSC (Fischer \& Resende, 2016). The symptoms of this disease are characterized by sudden wilting, collapse and death of the plants at any stage of development (Fischer \& Resende, 2016). Thus, the occurrence of colon rot drastically reduces the productivity and longevity of the crop and is responsible for constant migrations of the passion fruit plantations. This fact is aggravated by the fact that $F$. solani produces chlamydospores, which are structures that allow these pathogens to survive in the soil for several years (Fischer \& Resende, 2016).

There is no efficient control form for this disease, and the development of resistant cultivars would be a viable alternative, since there is no resistant passion fruit cultivar that has been registered so far. Thus, the only way to combat these problems is the transfer of resistance genes, found in wild species. In view of this, the genetic improvement research group of passion fruit at the State University of Mato Grosso (UNEMAT) has been conducting research aimed at obtaining cultivars resistant to soil pathogens, thus contributing to the genetic progress of the culture. This program started with the selection of wild Passiflora species resistant to $F$. solani and F. oxysporum f.sp. passiflorae (Preisigke et al., 2015, 2017). Subsequently, interspecific hybrids resistant to 
F. solani were obtained and currently, genotypes of the first generation of backcross are being developed (Marostega et al., 2020).

For genetic progress in breeding programs it is of great importance to estimate the genetic parameters, for this, the methodology of the mixed models REML/BLUP (maximum restricted likelihood/best non-impartial linear forecast) has been highly indicated due to its potential in estimating the gain genetic and better precision in the selection process in relation to selection indices or phenotypic selection (Freitas et al., 2013). Many authors (Santos et al., 2015; Silva et al., 2016, 2017), used the mixed REML/BLUP models to estimate the genetic parameters in the passion fruit culture.

Therefore, the objective of the work was to estimate genetic parameters and select genotypes resistant to colon rot in a segregating population from the first generation of backcrossing between $P$. edulis and interspecific hybrids, aiming at advancing generation in the passion fruit breeding program.

\section{Material and Methods}

The work was carried out at the Plant Breeding Laboratory, at the State University of Mato Grosso (UNEMAT), Cáceres campus, $16^{\circ} 11^{\prime} 42^{\prime \prime}$ south latitude and $57^{\circ} 40^{\prime} 51^{\prime \prime}$ west longitude, with temperature annual average of $26.24{ }^{\circ} \mathrm{C}$, total annual precipitation of $1,333 \mathrm{~mm}$ and altitude of $118 \mathrm{~m}$. The municipality integrates the mesoregion of the Center-South of Mato Grosso and the microregion of the Upper Pantanal, $215 \mathrm{~km}$ from the capital, where the climate is hot and humid tropical, with dry winter (Neves et al., 2011).

It was selected from the working collection of the Active Germplasm Bank of UNEMAT, the Inter-specific Hybrid (HI) UNEMAT 142, to be the pollen grain donor. This HI is the result of the cross between the resistant species P. nitida and the cultivar BRS Sol do Cerrado ( $P$. edulis), it has resistance to F. oxysporum f. sp. passiflorae and F. solani and was described by Marostega et al. (2020), as one of the genotypes selected to advance generation for resistance to soil fungi.

\subsection{Obtaining the Genotypes of the First Generation of Backcross (BCls)}

In order to recover the agronomic characteristics of the recurrent parent (P. edulis), a crossover between IH and $P$. edulis (BRS Sol do Cerrado) was carried out, obtaining the families of complete brothers (FCB) from the first generation of backcross (BC1).

The backcrosses were performed with three plants of P. edulis cultivar BRS Sol do Cerrado (plants 22, 28 and 113), and the transfer of pollen to the stigma was performed with the aid of forceps, carefully rubbing the anther about the stigma of each flower protected in pre-anthesis with a paper bag. The flowers were then labeled and, five days after pollination, the setting was verified.

The seeds of $\mathrm{BC} 1 \mathrm{~s}$, were sown in trays containing vermiculite substrate, kept in a screen covered with $50 \%$ shade. Subsequently, the seedlings were transplanted into $500 \mathrm{ml}$ plastic cups, and kept on a $50 \%$ covered shade screen until inoculation.

\subsection{Inoculation of F. solani}

The inoculation of $F$. solani was performed with the FSUNEMAT 40 inoculum, the most aggressive (Marostega et al., 2019). First, the preserved segments were transferred to Petri dishes containing PDA culture medium (potato-dextrose-agar) and maintained at $25^{\circ} \mathrm{C}$ with a $12 \mathrm{~h}$ photoperiod for seven days in the BOD.

The inoculation was performed with a mycelium disk of the pathogen of five millimeters in diameter and fixed with PVC plastic over a wound of three millimeters in diameter in the neck of the plant, at a height of two centimeters from the soil. Removing the PVC plastic five days after inoculation (DAI), according to the methodology of Fischer et al. (2005).

27 genotypes of $\mathrm{BC} 1 \mathrm{~s}$ were evaluated, with nine genotypes from each family of complete siblings (BC1-22, $\mathrm{BC} 1-28$ and $\mathrm{BC} 1-113)$. The evaluation of the resistance of the genotypes to $F$. solani was quantified through 10 resistance variables as described by Preisigke et al. (2015), which are:

- $\mathrm{SP}=$ Survival period;

- NDP = Number of dead plants;

- $\mathrm{LL}=$ Length of the lesion;

- $\mathrm{WL}=$ width of the lesion;

- NPL-50\% = Number of plants in which the lesion reached less than $50 \%$ of the circumference;

- PILA $50 \%=$ Period of inoculation until the lesion reaches $50 \%$ of the circumference; 
- PILA $100 \%=$ Period of inoculation until the lesion reaches $100 \%$ of the circumference;

- AULAEC = Area under the lesion area expansion curve;

- AULLEC = Area under the lesion length expansion curve;

- AULWEC $=$ Area under the lesion width expansion curve.

The evaluations were carried out after five days of inoculation, being carried out every two days until completing 33 days or until the death of the plants. The lesions were measured for their length and width of the necrotic area, with the aid of a digital caliper. The area of the lesion $\left(\mathrm{AL}, \mathrm{mm}^{2}\right)$ was estimated considering the formula for calculating the area of an ellipse $(\pi \cdot \mathrm{L} \cdot \mathrm{W} / 4)$, where $\mathrm{L}$ is the length of the lesion and $\mathrm{W}$ is the width of the lesion.

To estimate the components of variances, the method of maximum restricted likelihood (REML) was used and to select the best genotypes by the non-addicted linear prediction (BLUP) (Resende, 2002; Alves \& Resende, 2008).

REML/BLUP analyzes were performed using the Selegen-Reml/Blup program (Resende, 2016), which follows the statistical model $y=X r+Z g+W p+e$, where, $y$ is the vector of observations, $r$ is the vector of the effects of repetition (assumed to be fixed) added to the general average, $g$ is the vector of the individual genotypic effects (assumed to be random), $p$ is the vector of the effects of plots (random) and $e$, the vector of errors or residues (random). The capital letters represent the incidence matrices for the said effects. The statistical model used was the 147 of the Selegen program.

The following components of variance (REML) were estimated:

$\sigma_{\mathrm{g}}^{2}$ : genotypic variance between genotypes, equivalent to $1 / 2$ of the additive genetic variance plus $1 / 4$ of the dominance genetic variance, ignoring epistasis;

$\sigma_{\mathrm{f}}^{2}$ : individual phenotypic variance;

$\mathrm{h}_{\mathrm{a}}^{2}$ : individual heritability in the narrow sense, obtained by ignoring the fraction $(1 / 4)$ of the genetic dominance variance;

$\mathrm{h}^{2}{ }_{\mathrm{mp}}$ : heritability of the average of the genotypes, assuming complete survival and

Acprog: accuracy of genotype selection.

For the selection of the genotypes with the greatest genetic gains by the BLUP method (Best Linear Unbiased Prediction), the variables used were those in which the accuracy of the selection of the genotypes (Acprog), was above 0.50 . In addition, the variables were separated into two groups: a group with the variables in which the increase in the average gives resistance to the fungus, such as SP: which is the survival period of the plants and PILA 100\%: Period of inoculation until the lesion reaches $100 \%$ of circumference. The second group is formed with the variables in which the decrease in the average is what gives the resistance as the NDP: Number of dead plants, AULAEC: area under the expansion curve of the lesion area, AULLEC: area below the expansion curve of the lesion length and AULWEC: area below the lesion width expansion curve.

\section{Results and Discussion}

\subsection{Estimation of Genetic Parameters}

In general, the highest values of genotypic variance $\left(\sigma_{\mathrm{g}}^{2}\right)$, were for the variables SP and AULLEC, with 25.71 and $20.44 \%$ respectively, in relation to the phenotypic variance $\left(\sigma_{\mathrm{f}}^{2}\right)$ (Table 1$)$, that is, the genotypes evaluated showed considerable genetic variability for these characteristics. According to Cruz and Carneiro (2006), knowledge of the genotypic variation for breeding programs is extremely important, as it indicates the extent of genetic variation of a variable, with the use of breeding technologies. The variables that presented lower values of $\sigma_{\mathrm{g}}^{2}$, are NPL-50\% and WL, with 0.04 and $0.06 \%$ respectively, in relation to $\sigma_{\mathrm{f}}^{2}$, this indicates that these variables had a high environmental influence and should not be used to indicate genotypes promising. 
Table 1. Estimates of the components genotypic variance between genotypes $\left(\sigma_{\mathrm{g}}^{2}\right)$, individual phenotypic variance $\left(\sigma_{\mathrm{f}}^{2}\right)$, individual heritability in the strict sense $\left(\mathrm{h}_{\mathrm{a}}{ }_{\mathrm{a}}\right)$, heritability of the genotype mean $\left(\mathrm{h}_{\mathrm{mp}}{ }_{\mathrm{m}}\right)$ and accuracy of the selection of genotypes (Acprog) obtained by REML procedure, for the 10 variables evaluated in twenty-seven backcross genotypes resistant to the fungus $F$. solani

\begin{tabular}{|c|c|c|c|c|c|}
\hline $\begin{array}{ll}\text { Genetics } & \text { Parameters }\end{array}$ & $\sigma_{g}^{2}$ & $\sigma_{f}^{2}$ & $\mathbf{h}_{\mathrm{a}}^{2} \%$ & $\mathbf{h}^{2}{ }_{m p} \%$ & $A c_{\text {prog }}$ \\
\hline SP & 38.2997 & 148.9340 & 51.43 & 75.12 & 0.8667 \\
\hline NDP & 0.0185 & 0.2345 & 15.81 & 37.55 & 0.6127 \\
\hline $\mathbf{L L}$ & 0.0008 & 0.2101 & 0.82 & 1.87 & 0.1369 \\
\hline WL & 0.0960 & 153.2657 & 0.12 & 0.55 & 0.0746 \\
\hline NPL-50\% & 0.0092 & 20.7320 & 0.08 & 0.39 & 0.0628 \\
\hline PILA 50\% & 0.6756 & 164.7772 & 0.82 & 1.87 & 0.1369 \\
\hline PILA $100 \%$ & 6.2659 & 166.1458 & 7.54 & 25.89 & 0.5088 \\
\hline AULAEC & 24978.1116 & 566973.4560 & 8.81 & 28.91 & 0.5377 \\
\hline AULLEC & 2448.3118 & 11974.5827 & 40.89 & 69.47 & 0.8335 \\
\hline AULWEC & 239.9045 & 5197.5914 & 9.23 & 30.13 & 0.5489 \\
\hline
\end{tabular}

Note. SP: survival period; NDP: Number of dead plants; LL: Length of the lesion; WL: Width of the lesion; NPL-50\%: Number of plants in which the lesion reached less than 50\% of the circumference; PILA 50\%: Period of inoculation until the lesion reaches $50 \%$ of the circumference; PILA $100 \%$ : Period of inoculation until the lesion reaches $100 \%$ of the circumference; AULAEC: area below the lesion area expansion curve; AULLEC: area below the lesion length expansion curve; AULWEC: area under the lesion width expansion curve.

The values of individual heritability in the strict sense ranged from 0.08 to $51.43 \%$, with the lowest values observed for the characteristics NPL 50\% (0.08) and WL (0.12). The variables with the highest values were SP (51.43) and AULLEC (40.89).

The low values of heritability are due to the low value of the genetic variation associated with the high phenotypic variation, indicating a high environmental influence for these characteristics. However, according to Santos et al. (2015), even with low heritability variables, with the mixed models favorable genetic gains are expected, therefore, the use of these models in the present study is justified.

Contrasting result to that found by Freitas et al. (2015), who assessed the heritability for the AUDPC variable regarding CABMV resistance in a segregating population of passion fruit (Cowpea aphid-borne mosaic virus), found high heritability (94\%).

According to Silva et al. (2017), the accuracy value takes into account precision of the real value of the genetic variance based on the observed phenotypic variance. Low accuracy values indicate that possibly these variables are highly influenced by the environment and that the data for these variables are less reliable. In the present study, variables with accuracy values classified as high $(0.70 \leq$ Acprog $\leq 0.89)$ were found for the variables SP and AULLEC, with values of 0.8667 and 0.8335 , respectively. Variables classified as moderate $(0.50 \leq$ Acprog $\leq$ 0.69 ), for the variables NDP, PILA 100\%, AULAEC and AULWEC (Table 1) and the rest of the variables were classified with low accuracy values (Acprog $\leq 0.49$ ) (Resende \& Duarte, 2007).

\subsubsection{Individual Selection and Earnings Estimates}

From a total of 27 evaluated genotypes, the 10 best were selected for each of the analyzed variables, with genetic gains being predicted and the new averages estimated (Table 2). 
Table 2. Ranking of the twenty-seven genotypes with the highest estimates of genetic gain and new predicted averages, estimated via BLUP, in passion fruit genotypes from the first generation of backcross

\begin{tabular}{|c|c|c|c|c|c|c|c|c|c|}
\hline \multirow{2}{*}{ Ord. } & \multirow{2}{*}{ Genotypes } & \multicolumn{2}{|c|}{ SP } & \multirow{2}{*}{ Genotypes } & \multicolumn{2}{|c|}{ NDP } & \multirow{2}{*}{ Genotypes } & \multicolumn{2}{|c|}{ PILA $100 \%$} \\
\hline & & Gain (\%) & New media & & Gain (\%) & New media & & Gain (\%) & New media \\
\hline 1 & BC1-22/6 & 13.90 & 30.97 & BC1-22/6 & 0.0000 & 0.6667 & BC1-22/5 & 2.3391 & 23.7094 \\
\hline 2 & BC1-22/1 & 11.83 & 28.90 & BC1-22/7 & 0.0073 & 0.6740 & BC1-22/6 & 2.3391 & 23.7094 \\
\hline 3 & BC1-22/2 & 11.14 & 28.21 & BC1-22/3 & 0.0139 & 0.6806 & BC1-22/7 & 2.2386 & 23.6090 \\
\hline 4 & BC1-22/3 & 10.80 & 27.87 & BC1-22/2 & 0.0198 & 0.6865 & BC1-22/8 & 2.1884 & 23.5587 \\
\hline 5 & BC1-22/7 & 10.29 & 27.37 & BC1-22/1 & 0.0263 & 0.6929 & BC1-22/1 & 2.0843 & 23.4547 \\
\hline 6 & BC1-113/3 & 9.72 & 26.80 & BC1-113/3 & 0.0332 & 0.6999 & BC1-22/2 & 2.0149 & 23.3853 \\
\hline 7 & BC1-22/8 & 9.24 & 26.31 & BC1-113/8 & 0.0388 & 0.7055 & BC1-22/3 & 1.9654 & 23.3357 \\
\hline 8 & BC1-113/7 & 8.71 & 25.78 & BC1-113/7 & 0.0441 & 0.7108 & BC1-22/4 & 1.8329 & 23.2033 \\
\hline 9 & BC1-113/8 & 8.29 & 25.37 & BC1-22/5 & 0.0500 & 0.7166 & BC1-22/9 & 1.6841 & 23.0545 \\
\hline 10 & BC1-22/4 & 7.77 & 24.84 & BC1-22/4 & 0.0555 & 0.7222 & BC1-28/6 & 1.5598 & 22.9301 \\
\hline
\end{tabular}

Note. SP: survival period; NDP: Number of dead plants and PILA 100\%: Period of inoculation until the lesion reaches $100 \%$ of the circumference.

Table 2. Continued

\begin{tabular}{|c|c|c|c|c|c|c|c|c|c|}
\hline \multirow{2}{*}{ Ord. } & \multirow{2}{*}{ Genotypes } & \multicolumn{2}{|c|}{ AULAEC } & \multirow{2}{*}{ Genotypes } & \multicolumn{2}{|c|}{ AULLEC } & \multirow{2}{*}{ Genotypes } & \multicolumn{2}{|c|}{ AULWEC } \\
\hline & & Gain (\%) & New media & & Gain (\%) & New media & & Gain (\%) & New media \\
\hline 1 & BC1-28/4 & 0.0000 & 44.6868 & BC1-28/4 & 0.0000 & 6.9660 & BC1-28/4 & 0.0000 & 3.6209 \\
\hline 2 & BC1-28/5 & 0.0165 & 44.7034 & BC1-28/7 & 0.0406 & 7.0066 & BC1-28/1 & 0.0076 & 3.6286 \\
\hline 3 & BC1-28/8 & 0.0327 & 44.7196 & BC1-28/3 & 0.0802 & 7.0462 & BC1-28/3 & 0.0146 & 3.6355 \\
\hline 4 & BC1-28/1 & 0.0478 & 44.7346 & BC1-28/1 & 0.1221 & 7.0881 & BC1-28/5 & 0.0222 & 3.6431 \\
\hline 5 & BC1-28/3 & 0.0641 & 44.7509 & BC1-28/5 & 0.1676 & 7.1336 & BC1-28/7 & 0.0298 & 3.6507 \\
\hline 6 & BC1-28/6 & 0.0819 & 44.7687 & BC1-28/8 & 0.2152 & 7.1811 & BC1-28/2 & 0.0380 & 3.6589 \\
\hline 7 & BC1-28/2 & 0.1006 & 44.7874 & BC1-28/2 & 0.2578 & 7.2237 & BC1-28/6 & 0.0458 & 3.6667 \\
\hline 8 & BC1-28/7 & 0.1204 & 44.8072 & BC1-28/6 & 0.3033 & 7.2693 & BC1-28/9 & 0.0544 & 3.6753 \\
\hline 9 & BC1-28/9 & 0.1413 & 44.8281 & BC1-28/9 & 0.3503 & 7.3163 & BC1-28/8 & 0.0627 & 3.6836 \\
\hline 10 & BC1-22/5 & 0.1600 & 44.8468 & BC1-113/4 & 0.3874 & 7.3534 & BC1-22/5 & 0.0719 & 3.6929 \\
\hline
\end{tabular}

Note. AULAEC: area below the lesion area expansion curve; AULLEC: area below the lesion length expansion curve and AULWEC: area below the lesion width expansion curve.

In the selection of genotypes by the BLUP procedure, it was observed that the genetic gains obtained for the SP variable ranged from 13.9 to $7.77 \%$, with the ten selected genotypes being: $\mathrm{BC} 1-22 / 6, \mathrm{BC} 1-22 / 1, \mathrm{BC} 1-22 / 2$, $\mathrm{BC} 1-22 / 3, \mathrm{BC} 1-22 / 7, \mathrm{BC} 1-22 / 8, \mathrm{BC} 1-22 / 4, \mathrm{BC} 1-113 / 3, \mathrm{BC} 1-113 / 7$ and $\mathrm{BC} 1-113 / 8$. A similar result was found for the NDP variable, where most of the genotypes selected for the SP characteristic were also selected for the NDP characteristic, with the exception of the BC1-22/8 genotype, which in its place was selected the BC1-22/5 genotype. The genetic gain values for this variable were from 0.00 to $0.0555 \%$.

For the variable PILA $100 \%$, the selected genotypes were similar to those found for the variables SP and NDP, however, in addition to the genotypes $\mathrm{BC} 1-22 / 5, \mathrm{BC} 1-22 / 6, \mathrm{BC} 1-22 / 7, \mathrm{BC} 1-22 / 8, \mathrm{BC} 1-22 / 1, \mathrm{BC} 1-22 / 2$, $\mathrm{BC} 1-22 / 3$ and $\mathrm{BC} 1-22 / 4$, which have already been selected, in this variable the genotypes $\mathrm{BC} 1-22 / 9$ and $\mathrm{BC} 1-28 / 6$ were also selected. The genetic gains ranged from 2.33 to $1.55 \%$.

However, for the variables related to the area under the lesion area expansion curve, lesion length and lesion width (AULAEC, AULLEC and AULWEC), the best ranked genotypes were BC1-28/1, BC1-28/2, BC1-28/3, $\mathrm{BC} 1-28 / 4, \mathrm{BC} 1-28 / 5, \mathrm{BC} 1-28 / 6, \mathrm{BC} 1-28 / 7$ and $\mathrm{BC} 1-28 / 9$. These variables are directly related to the CC and $\mathrm{WL}$ variables, and these genotypes only showed low values of $\mathrm{CC}$ and WL because they also presented low values of SP, for example, the genotypes BC1-28/1, BC1-28/3 and BC1 -28/7, had only five days of survival (SP), therefore, even with a low value of $\mathrm{CC}$ and WL, they were unable to survive the damage caused by the fungus $F$. solani, therefore, they are not selected to continue the program of improvement. 
Thus, the characteristics SP, NDP and PILA 100\% are the ones that best distinguish resistant genotypes, therefore, only the genotypes selected based on these variables, in this study, will be part of the advancement of the breeding program aiming resistance to rot the lap.

By the BLUP procedure, in general, most of the selected genotypes come from family 22, indicating that the parent involved in this crossing is efficient in transferring the resistance gene to the offspring. However, it was possible to select genotypes from all families. Thus, the importance of carrying out individual selection, since there is a very large variation within families at this stage of the program.

\section{Conclusion}

The variables that showed the highest heritability values were the survival period and the area under the lesion length expansion curve.

The three families of backcrosses presented genotypes resistant to the fungus $F$. solani, however, by the methodology of mixed models REML/BLUP, only the genotypes BC1-22/1, BC1-22/2, BC1-22/3, BC1-22/4, $\mathrm{BC} 1-22 / 6, \mathrm{BC} 1-22 / 7, \mathrm{BC} 1-113 / 3, \mathrm{BC} 1-113 / 7$ and $\mathrm{BC} 1-113 / 8$, were selected to advance the generation of the UNEMAT passion fruit breeding program, therefore, they presented among the ten placed, mainly for the variable survival period (SP).

\section{References}

Alves, F. M., \& Resende, M. D. V. (2008). Avaliação genética de indivíduos e progênies de cupuaçuzeiro no estado do Pará e estimativas de parâmetros genéticos. Revista Brasileira de Fruticultura, 30, 696-701. https://doi.org/10.1590/S0100-29452008000300023

Bernardo, R. (2002). Genotype $\times$ environment interaction. In R. Bernardo (Ed.), Breeding for quantitative traits in plants (pp. 147-171). Stemma Press, Woodbury.

Cervi, A. C. (1997). Passifloraceae do Brasil: Estudo do gênero Passiflora L., subgênero Passiflora. Fontqueria, 45, 1-92.

Cruz, C. D. (2016). Genes Software-Extended and integrated with the R, Matlab and Selegen. Acta Scientiarum, 38(4), 547-552. https://doi.org/10.4025/actasciagron.v38i3.32629

Cruz, C. D., \& Carneiro, P. C. S. (2006). Biometric models applied to genetic improvement (2nd ed.). Imprensa Universitária, Viçosa.

Dhawan, K., Dhawan, S., \& Sharma, A. (2004). Passiflora: A review update. J. Ethnopharmacol., 94, 1-23. https://doi.org/10.1016/j.jep.2004.02.023

Fischer, I. H., Lourenco, S. A., Martins, M. C., Kimati, H., \& Amorim, L. (2005). Seleção de plantas resistentes e de fungicidas para o controle da podridão do colo do maracujazeiro causada por Nectria haematococca. Fitopatologia Brasileira, 30, 250-258. https://doi.org/10.1590/S0100-41582005000300006

Fischer, I. H., \& Resende, J. A. M. (2016). Doenças do maracujazeiro. In L. Amorim, J. A. M. Rezende, A. Bergamin Filho \& L. E. A. Camargo (Eds.), Manual de Fitopatologia: Doenças das plantas Cultivadas (Vol. 5, pp. 535-544). São Paulo: Agronômica Ceres.

Freitas, I. L. D. J., Amaral Junior, A. T., Viana, A. P., Pena, G. F., Cabral, P. S., Vittorazzi, C., \& Silva, T. R. D. C. (2013). Genetic gain evaluated with selection indices and with REML/Blup in popcorn. Pesq. Agrop. Bras., 48, 1464-1471. https://doi.org/10.1590/S0100-204X2013001100007

Freitas, J. C. O., Viana, A. P., Santos, E. A., Paiva, C. L., Rodrigues, R., Souza, M. M., \& Eiras, M. (2015). Genetic basis of the resistance of a passion fruit segregant population to Cowpea Aphid-Borne Mosaic Virus (CABMV). Tropical Plant Pathology, 40, 291-297. https://doi.org/10.1007/s40858-015-0048-2

IBGE. (2020). Diretoria de Pesquisa, Coordenação de Agropecuária, Produção Agrícola Municipal 2019. Retrieved January 29, 2020, from https://sidra.ibge.gov.br/tabela/5457\#resultado

Lopes, S. C. (1991). Citogenética do maracujá, Passiflora spp. In A. R. São José (Eds.), A cultura do maracujá no Brasil (pp. 201-209). Jaboticabal: FUNEP.

Marostega, T. N., Lara, L. P., Oliveira, D. S., Chimello, A. M., Gilio, T. A. S., Preisigke, S. C., .. Neves, L. G. (2019). Molecular and Aggressiveness Characterization of Isolates of Fusarium solani and Fusarium oxysporum f.sp. passiflorae Associated to Passion Fruit Wilting. Journal of Agricultural Science, 11, 01-14. https://doi.org/10.5539/jas.v11n3p407 
Marostega, T. N., Preisigke, S. C., Chimello, A. M., Gilio, T. A. S., Araujo, K. L., Barelli, M. A. A., \& Neves, L. G. (2020). Genetic resistance to fusariosis and base rot in interspecific F1 progenies of passion fruit (Passiflora spp.). Research, Society and Development, 9, 1-25. https://doi.org/10.33448/rsd-v9i11.10519

Meletti, L. M., \& Maia, M. L. (1999). Maracujá: Produção e comercialização. Boletim Técnico 181 (pp. 1-64). IAC: Campinas.

Neves, L. G., Bruckner, C. H., Picanço, M. C., Sobrinho, S. P., Araújo, K. L., Luz, P. B., .. Krause, W. (2013). Genetic correlation between agronomically important traits in yellow passion fruit. Amer J Plant Sci, 4, 2112-2117. https://doi.org/10.4236/ajps.2013.411262

Neves, S. M. A. S., Nunes, M. C. M., \& Neves, R. J. (2011). Caracterização das condições climáticas de Cáceres/MT Brasil, no período de 1971 a 2009: Subsídio às atividades agropecuárias e turísticas municipais. Boletim Goiano Geográfico, 31, 55-68. https://doi.org/10.5216/bgg.v31i2.16845

Preisigke, S. C., Martini, F. V., Rossi, A. A. B., Serafim, M. E., Barelli, M. A. A., Luz, P. B., ... Neves, L. G. (2015). Genetic variability of Passiflora spp. against collar rot disease. Aust. J. Crop. Sci., 9, 69-74.

Preisigke, S. C., Silva, L. P., Serafim, M. E., Bruckner, C. H., Araújo, K. L., \& Neves, L. G. (2017). Seleção precoce de espécies de Passiflora resistente a fusariose. Summa Phytopathologica, 43, 321-325. https://doi.org/10.1590/0100-5405/175390

Resende, M. D. V. (2002). Genética biométrica e estatística no melhoramento de plantas perenes (p. 975). Brasília: Embrapa Informação Tecnológica.

Resende, M. D. V. (2016). Software Selegen-REML/BLUP: A useful tool for plant breeding. Crop Breed. Appl. Biotechnol., 16, 330-339. https://doi.org/10.1590/1984-70332016v16n4a49

Resende, M. D. V., \& Duarte, J. B. (2007). Precisão e controle de qualidade em experimentos de avaliação de cultivares. Pesquisa Agropecuária Brasileira, 37, 182-194.

Santos, E. A., Viana, A. P., Freitas, J. C. O., Rodrigues, D. L., Tavares, R. F., Paiva, C. L., \& Souza, M. M. (2015). Genotype selection by REML/BLUP methodology in a segregating population from an interspecific Passiflora spp. crossing. Euphytica, 204, 1-11. https://doi.org/10.1007/s10681-015-1367-6

Silva, F. H. L., Viana, A. P., Santos, E. A., Freitas, J. C. O., Rodrigues, D. L., \& Amaral Junior, A. T. (2017). Prediction of genetic gains by selection indexes and REML/BLUP methodology in a population of sour passion fruit under recurrent selection. Acta Scientiarum Agronomy, 39. https://doi.org/10.4025/actasciagron. v39i2.32554

Silva, F. H. L., Muñoz, P. R., Vincent, C. I., \& Viana, A. P. (2016). Generating relevant information for breeding Passiflora edulis: Genetic parameters and population structure. Euphytica, 208, 609-619. https://doi.org/ 10.1007/s10681-015-1616-8

Viana, A. P., Pereira, T. N. S., Pereira, M. G., Amaral Júnior, A. T., Souza, M. M., \& Maldonado, J. F. M. (2004). Genetic parameters in populations of yellow passion fruit. Revista Ceres, 51, 541-551. https://doi.org/ 10.1590/S1516-89132009000300002

Wijeratnam, S. W. (2016). Passion Fruit. Encyclopedia of Food and Health, 23, 231-235. https://doi.org/ 10.1016/B978-0-12-384947-2.00521-3

\section{Copyrights}

Copyright for this article is retained by the author(s), with first publication rights granted to the journal.

This is an open-access article distributed under the terms and conditions of the Creative Commons Attribution license (http://creativecommons.org/licenses/by/4.0/). 